\title{
UPAYA PENINGKATAN KEMAMPUAN MENDENGARKAN DONGENG MELALUI TEKNIK SIMAK ULANG UCAP SISWA KELAS VII.6 SMPN 21 KOTA PEKANBARU
}

\author{
Sri Utami Indriani Putri \\ SMP Negeri 21 Pekanbaru \\ e-mail: sriutami1964@gmail.com
}

\begin{abstract}
This research is motivated by the low ability of students to listen to the fairy tale, the lack of ability of the students of class VII.6 to distinguish between words consonant and vowel is the symptoms seen in the implementation of teaching and learning process. The purpose of this classroom action research is to improve the listening ability of students of Class VII.6 SMPN 21 Pekanbaru. In order for this classroom action research process to be carried out without any obstacles that may interfere with the smoothness of this research, the researchers set up several stages to be carried out in classroom action research: first stage Planning / preparation of action, second stage Implementation of action, and third stage Observation, and Reflection.

Based on the results of the research, it can be seen that listening to tales has increased. Where is known from the average score of students' ability on the initial data is 76.4 (enough) with $38.6 \%$ complete students or 17 people. The first cycle obtained an average of 79.4 (good) with a mastery of $65.9 \%$ students or 29 people. The results of the learning process of the students of Class VII.6 SMPN 21 Pekanbaru Town in the second cycle increased by an average of 83.2 (good) with a completeness of 44 students or $100 \%$. Based on the results of the data then this research is said to be successful because more than $85 \%$ of students have obtained a value of $78-100$.
\end{abstract}

Keywords: Listening, Tales, Listening to Ucap

\begin{abstract}
Abstrak
Penelitian ini dilatarbelakangi oleh rendahnya kemampuan siswa dalam mendengarkan dongeng, kurang mampunya siswa kelas VII.6 membedakan bunyi kata antara konsonan dan vokal merupakan gejala-gejala yang terlihat dalam pelaksanaan proses belajar mengajar. Tujuan penelitian tindakan kelas ini adalah untuk meningkatkan kemampuan mendengarkan dongeng siswa Kelas VII.6 SMPN 21 Kota Pekanbaru. Agar proses penelitian tindakan kelas ini dapat terlaksana tanpa hambatan yang dapat mengganggu kelancaran dari penelitian ini, maka peneliti menyusun beberapa tahapan yang akan dilaksanakan dalam penelitian tindakan kelas, yaitu: taha pertama Perencanaan/persiapan tindakan, tahap kedua Pelaksanaan tindakan, dan tahap ketiga Observasi, dan Refleksi.

Berdasarkan hasil penelitian, maka dapat diihat bahwa mendengarkan dongeng mengalami peningkatan. Di mana diketahui dari rata-rata nilai kemampuan siswa pada data awal adalah 76.4 (cukup) dengan ketuntasan 38.6\% siswa atau 17 orang. Siklus pertama diperoleh rata-rata 79.4 (baik) dengan ketuntasan 65.9\% siswa atau 29 orang. Hasil dari proses belajar dari siswa Kelas VII.6 SMPN 21 Kota Pekanbar pada siklus kedua meningkat dengan rata-rata 83.2 (baik) dengan ketuntasan 44 siswa atau 100\%. Berdasarkan hasil data tersebut maka penelitian ini dikatakan berhasil, karena lebih dari $85 \%$ siswa telah memperoleh nilai $78-100$
\end{abstract}

Kata kunci : Mendengarkan, Dongeng, Simak Ulang Ucap

\section{PENDAHULUAN}

Kemampuan mendengarkan merupakan salah satu dari keterampilan yang sangat dibutuhkan manusia. Banyak pengetahuan, pengalaman yang diperoleh seseorang melalui kegiatan mendengarkan, untuk sampai pada tahap keterampilan berbahasa yang lain seperti berbicara, 
membaca dan menulis tidak akan pernah dapat dilakukan seseorang tanpa didahului oleh kegiatan mendengarkan. Sebagaimana dikemukakan oleh Razak mendengarkan adalah salah satu dari empat bagian komponen bahasa. Mendengarkan merupakan komponen bahasa tingkatan pertama. Sejak manusia masih dalam kandungan proses mendengarkan sudah mulai berlangsung. Hal ini dapat diterima dimana para ibu-ibu yang sedang hamil dianjurkan untuk memperdengarkan musik-musik lembut berisi ajaran moral yang positif agar sijabang bayi terbiasa dan peka terhadap bunyi apa yang didengarnya.

Berdasarkan hasil pengamatan peneliti, kenyataan dilapangan masih jauh dari harapanharapan yang ada. Dewasa ini kegiatan belajar adalah bagian dari proses pendidikan bagi anak didik semakin mengalami kemunduran. Belajar semakin dianggap suatu kegiatan membosankan dan tidak berkembang. Pada tiap sekolah, situasinya tidak jauh berbeda, anak-anak umumnya kurang memiliki keterampilan dan kurang aktif dalam belajar khususnya dalam belajar Bahasa Indonesia. Guru mengajar masih mengunakan materi yang sama setiap tahunnya atau catatan yang sama, gaya mengajar tidak berubah, banyaknya materi hapalan tanpa menggunakan media pengajaran, standar, formal dan baku.

Proses pembelajaran di SMPN 21 Kota Pekanbaru khususnya pada Kelas VII.6 guru masih menggunakan teknik ceramah. Teknik ceramah adalah salah satu teknik yang 'murah' dan 'mudah' untuk dapat dilakukan. Yang dimaksud dengan Murah adalah proses ceramah tidak membutuhkan penunjang berupa peralatan-peralatan yang lengkap, hal ini berbeda dengan teknik yang lain. Sedangkan mudah, memang ceramah hanya mengandalkan suara guru, dengan demikian tidak terlalu memerlukan siapan yang rumit. Namun dalam kenyataan peneliti melihat penggunaan teknik ceramah dalam proses pembelajaran hanya yang menguasai pembelajaran dengan baik hanya guru yang bertugas menyampaikan materi pelajaran, sedangkan siswa hanya terbatas pengatahuan yang dikuasai oleh guru.

Akibat yang timbul dari teknik ceramah yang digunakan guru dalam proses pembelajaran siswa cendrung bosan dengan materi pelajaran yang sedang diberikan oleh guru sehingga hasil belajar dari siswa kurang memuaskan. Selanjutnya pada proses pelaksanaan pembelajaran guru mendukung teknik ceramah dengan menggunakan teknik demontrasi, dimana siswa diminta untuk mempraktekkan materi yang telah disampaikan oleh guru. Namun peneliti melihat hasil belajar siswa juga kurang memuaskan.

Berdasarkan pengalaman peneliti selama mengajar di Kelas Kelas VII.6 SMPN 21 Kota Pekanbaru ditemui berbagai masalah berikut:

1. Sebagian siswa dikelas VII.6 kurang tanggap terhadap pelajaran bahasa Indonesia yang diberikan oleh guru ketika pembelajaran berlangsung, hal ini terbukti ketika diajukan pertanyaan siswa tidak mampu menjawab.

2. Dari 44 jumlah siswa dikelas VII.6 hanya 3 sampai 6 orang siswa saja yang mampu menjawab pertanyaan dengan sempurna ketika ulangan.

3. Sebagian siswa kelas VII.6 kurang mampu membedakan bunyi kata antara konsonan dan vokal.

4. Dari data awal hanya 17 orang siswa atau $38.6 \%$ dari 44 siswa yang telah mampu mencapai nilai KKM yang ditetapkan yaitu 75

Sesuai berbagai permasalahan yang dikemukakan di atas, peneliti sebagai guru perlu mencari upaya agar permasalahan tersebut tidak terus terjadi. Upaya yang bisa dilakukan oleh guru adalah dengan mencari model pembelajaran yang tepat untuk menyelesaikan permasalahan yang dihadapi tersebut. Peneliti merasa tertarik dan ingin melaksanakan penelitian berupa penelitian tindakan sebagai upaya dalam melakukan perbaikan terhadap pembelajaran dengan judul "Upaya Peningkatan Kemampuan Mendengarkan Dongeng Melalui Teknik Simak Ulang Ucap Siswa Kelas Kelas VII.6 SMPN 21 Kota Pekanbaru".

\section{METODOLOGI}

\subsection{Tempat Penelitian}

Penelitian ini dilaksanakan pada siswa Kelas VII.6 Sekolah Menengah Pertama (SMP) Negeri 21 Kota Pekanbaru. 


\subsection{Subjek Penelitian}

Subjek penelitian ini adalah siswa Kelas VII.6 SMPN 21 Kota Pekanbaru dengan jumlah 44 orang, yang terdiri dari 21 siswa laki-laki dan 23 siswa perempuan.

Kemampuan Siswa dalam Mendengarkan dongeng

Pengolahan dilakukan dengan cara pengumpulan klasifikasi dan mengalisis data sebelum data awal dianalisis terlebih dahulu ditentukan kriteria-kriteria penilaian untuk kemampuan mendengarkan. Kriteria-kriteria tersebut digunakan untuk mengetahui sejauh mana kemampuan mendengarkan siswa, yaitu siswa mampu menentukan tema atau pesan. Kemudian untuk menentukan kriteria kemampuan mendengarkan dongeng yang diperoleh siswa, maka ditentukan melalui interval berikut.

Tabel 1

Interval Kategori Kemampuan Mendengarkan dongeng

\begin{tabular}{ccc} 
No & Interval (\%) & Kategori \\
\hline 1 & $90-100$ & Baik Sekali \\
\hline 2 & $80-89$ & Baik \\
\hline 3 & $70-79$ & Cukup \\
\hline 4 & $<70$ & Kurang \\
\hline
\end{tabular}

Sumber: Yeti (2009:8.33)

\section{HASIL PENELITIAN DAN PEMBAHASAN}

Kemampuan mendengarkan dongeng yang diperoleh oleh siswa Kelas Kelas VII.6 SMPN 21 Kota Pekanbaru mengalami peningkatan dari tes awal ke siklus pertama dan siklus kedua.

Tabel 2

Rekapitulasi Kemampuan Siswa

\begin{tabular}{|c|c|c|c|c|}
\hline Skor & Kategori & Data Awal & Siklus I & Siklus II \\
\hline $90-100$ & $\begin{array}{c}\text { Baik } \\
\text { Sekali }\end{array}$ & $-(0 \%)$ & $\begin{array}{c}1 \text { siswa } \\
(2.3)\end{array}$ & $\begin{array}{c}7 \text { siswa } \\
(15.9 \%)\end{array}$ \\
\hline $80-89$ & Baik & $\begin{array}{c}16 \text { siswa } \\
(36.4 \%)\end{array}$ & $\begin{array}{c}28 \text { siswa } \\
(63.6 \%)\end{array}$ & $\begin{array}{c}37 \text { siswa } \\
(84.1 \%)\end{array}$ \\
\hline $70-79$ & Cukup & $\begin{array}{c}18 \text { siswa } \\
(63.6 \%)\end{array}$ & $\begin{array}{c}15 \text { siswa } \\
(34.1 \%)\end{array}$ & $-(0 \%)$ \\
\hline$<70$ & Kurang & $-(0 \%)$ & $-(0 \%)$ & $-(0 \%)$ \\
\hline \multicolumn{2}{|c|}{ Rata-rata } & 76.4 & 79.4 & 83.2 \\
\hline \multicolumn{2}{|c|}{ Kategori } & Cukup & Cukup & Baik \\
\hline $\begin{array}{r}\text { Siswa yang Tuntas } \\
\text { Siswa yang Tidak }\end{array}$ & $\begin{array}{c}17 \text { siswa } \\
(38.6 \%)\end{array}$ & $\begin{array}{c}29 \text { siswa } \\
(65.9 \%)\end{array}$ & $\begin{array}{c}44 \text { siswa } \\
(100 \%)\end{array}$ \\
\hline \multicolumn{2}{|c|}{ Tuntas } & $\begin{array}{c}15 \text { siswa } \\
(61.4 \%)\end{array}$ & $-(0 \%)$ \\
\hline \multicolumn{2}{|c|}{$(34.1 \%)$} & \\
\hline
\end{tabular}




\begin{tabular}{|c|c|c|c|}
\hline Jumlah Siswa & 44 & 44 & 44 \\
\hline
\end{tabular}

Diketahui dari tabel 7, rata-rata nilai kemampuan siswa pada data awal adalah 76.4 (cukup) dengan ketuntasan $38.6 \%$ siswa atau 17 orang. Siklus pertama diperoleh rata-rata 79.4 (baik) dengan ketuntasan $65.9 \%$ siswa atau 29 orang. Hasil belajar siswa pada siklus kedua meningkat dengan rata-rata 83.2 (baik) dengan ketuntasan 44 siswa atau 100\%. Peningkatan kemampuan siswa dari data awal ke siklus pertama dan kedua juga dapat dilihat dalam bentuk gambar di bawah ini.

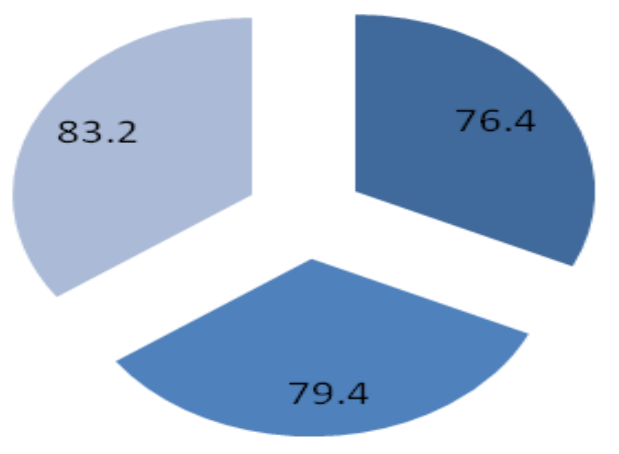

Gambar 2. Perbandingan Rata rata Kemampuan dari Data Awal, Siklus I, dan Siklus II

Berdasarkan tabel 2 dan gambar 2, maka penulis hanya melakukan dua siklus tindakan. Karena sudah jelas hasil yang diperoleh dari penelitian, yaitu meningkatnya kemampuan mendengarkan dongeng siswa Kelas Kelas VII.6 SMPN 21 Kota Pekanbaru dalam dengan penerapan teknik simak ulang ucap.

\section{KESIMPULAN}

Diketahui bahwa penelitian ini bertujuan untuk meningkatkan kemampuan kemampuan mendengarkan dongeng melalui teknik simak ulang ucap siswa Kelas Kelas VII.6 SMPN 21 Kota Pekanbaru. Pernyataan ini dapat diterima, karena kemampuan siswa dalam kemampuan mendengarkan dongeng mengalami peningkatan. Di mana dikatehui dari rata-rata nilai kemampuan siswa pada data awal adalah 76.4 (cukup) dengan ketuntasan 38.6\% siswa atau 17 orang. Siklus pertama diperoleh rata-rata 79.4 (baik) dengan ketuntasan 65.9\% siswa atau 29 orang. Hasil belajar siswa pada siklus kedua meningkat dengan rata-rata 83.2 (baik) dengan ketuntasan 44 siswa atau 100\%. Dengan demikian penelitian ini dikatakan berhasil, karena lebih dari $85 \%$ siswa telah memperoleh nilai $78-100$.

\section{SARAN}

Melalui simpulan hasil peneltian di atas, maka peneliti ingin menyampaikan beberapa saran. Adapun saran yang dimaksud adalah sebagai berikut:

1. Untuk meningkatkan kemampuan mendengarkan dongeng di sekolah diharapkan kepada Guru Bahasa Indonesia dan Sastra dapat menggunakan teknik simak ulang ucap. Dan hendaknya guru diharapkan lebih sering menerapkan strategi tersebut. Sehingga hasil yang diperoleh dapat terus meningkat sesuai harapan sekolah.

2. Kepada peneliti selanjutnya agar meneliti lebih dalam tentang mendengarkan dan teknik simak ulang ucap demi kesempurnaan penelitian selanjutnya. 
3. Kepada kepala sekolah perlu memamtau dan membina terhadap dampak kegiatan Penelitian Tindakan Kelas (PTK), sebagai bahan penilaian kemajuan yang telah dicapai, sehingga apa yang ditemukan pada PTK dapat diimplementasikan dalam pelaksanaan pembelajaran di sekolah.

4. Kepada pengawas perlu mengadakan kunjungan supervisi terhadap peneliti dalam pelaksanaan PTK sedang berlangsung, agar apa yang ditemukan dapat diimplementasikan pada proses pelaksanaan pembelajaran

\section{DAFTAR PUSTAKA}

[1] Arikunto, Suharsimi. 2007. Penelitian Tindakan Kelas. Jakarta: Bumi Aksara.

[2] Abbas, Saleh. 2006. Pembelajaran Bahasa Indonesia yang Efektif di Sekolah Dasar. Jakarta: Depdikbud.

[3] Arikunto, Suharsimi.2006. Prosedur Penelitian Suatu Pendekatan Praktek. Jakarta: Rineka Cipta.

[4] Depdikbud. 2002. Kamus Besar Bahasa Indonesia. Jakarta: Balai Pustaka.

[5] Hasan, Alwi. 1992. Tata Bahasa Baku Bahasa Indonesia. Jakarta: Balai Pustaka.

[6] KTSP. 2007. Panduan Lengkap KTSP. Yokyakarta: Pustaka Yudhisia.

[7] Mukhtar dan Anilawati. 2006. Menyimak. Pekanbaru: Cendikia Insani.

[8] Razak. 2003. Bahasa Indonesia Versi Perguruan Tinggi. Pekanbaru: Autografika.

[9] Sanjaya, Wina. 2007. Strategi Pembelajaran. Jakarta: PT. Kencana.

[10] Slamet. 2007. Dasar-dasar Pembelajaran Bahasa dan Sastra Indonesia di Sekolah dasar. Surakarta: Lembaga Pengembangan Pendidikan (LPP) UNS dan UPT. Penerbitan dan Percetakan UNS Press).

[11] Tarigan, Djago, dkk. 2001. Pendidikan Keterampilan Berbahasa. Jakarta: Universitas Terbuka.

[12] Tim Penyusun EYD. 1975. Pedoman Umum Ejaan Bahasa Indonesia yang Disempurnakan. Jakarta: Pusat

Pembinaan dan Pengembangan Bahasa Departemen Pendidikan dan Kebudayaan. Balai Pustaka.

[13] Wardani. 2002. Penelitian Tindakan Kelas. Jakarta: UT.

[14] Yeti. 2009. Keterampilan Berbahasa Indonesia SD. Jakarta: UT. 